\title{
THE EFFECT OF INTERNAL AND EXTERNAL MECHANISM ON CORPORATE SOCIAL RESPONSIBILITY DISCLOSURE
}

\author{
Astrid Rudyanto ${ }^{1^{*}}$ \\ ${ }^{1}$ STIE Trisakti, Indonesia
}

\begin{abstract}
Corporate social responsibility disclosure should be controlled by internal and external mechanism to make sure that company is doing its business morally. Board of commissioners are responsible for supervising company from internal. This study uses board (of commissioner) diversity as internal mechanism. Board diversity is measured by board size, women on board, and board tenure. Public visibility acts as external mechanism to watch corporate social responsibility disclosure. Public visibility is measured by firm size, profitability, and listing age. Corporate social responsibility disclosure is measured using content analysis made by Sembiring (2005). This study aims to examine the effect of board diversity and public visibility on corporate social responsibility disclosure. Using 177 manufacturing companies listed in Indonesia Stock Exchange in the period of 2013-2015, the result shows substitution association of internal and external mechanism on corporate social responsibility disclosure. This shows that one of those mechanisms is enough to increase corporate social responsibility disclosure and regulator shall consider external mechanism for making regulation on internal mechanism.
\end{abstract}

Keywords: board diversity, corporate social responsibility disclosure, external mechanism, internal mechanism, public visibility

\section{INTRODUCTION}

Since 2007, Indonesian government has required listed companies disclose corporate social responsibility with the hope of making it as the bridge of the commercial companies profit and moralist corporate social responsibility. However, there are still tremendous numbers of corporate social responsibility violation in Indonesia, for instance in 2016, the case of PT Jaya Mestika Indonesia, one of the listed manufacturing companies, which dumped its hazardous waste recklessly (Detik, 2016). If the government law cannot make the listed companies to do social responsibility, who can? Purwanto(2011) indicates that making corporate social responsibility as a mandatory disclosure is just degrading social responsibility into social obligation. Responsibility should be coming from companies' morality. Nonetheless, it is extremely hard to rely on companies' morality. There has to be special supervisory mechanism to enforce companies to become moralist.

The supervisory mechanism divided into two groups, which are internal and external mechanism. The internal mechanism is board of commissioner. Board of commissioner is board that has supervisory role to board of director (Pemerintah Republik Indonesia, 2007). The diverse characteristics of board of commissioner members are crucial in companies' decision, especially when it comes to corporate social responsibility. There are at least two reasons. First, the board diversity oblige company to reveal diversity practice, which is desired by stakeholders in making corporate social responsibility activities and reports(Bear, Rahman, \& Post, 2010). Second, by having diverse board with different expertise, company will get valuable information and consideration in decision making, especially regarding corporate social responsibility (Handajani, Subroto, \& Erwin, 2014).The external mechanism is from public, which is public pressure. The more visible the company is, the more pressure it gets from society and the more disclosure it has to publish to hinder the negative reaction (Branco \& Rodrigues, 2008).

* Corresponding author. Email address : astrid@stietrisakti.ac.id 
Previous researches concentrate on director's role on corporate social responsibility disclosure(Frias-Aceituno, Rodriguez-Ariza, \& Garcia-Sanchez, 2013; Kathy Rao, Tilt, \& Lester, 2012; Rao \& Tilt, 2016a) and do not evaluate supervisor's role on corporate social responsibility disclosure. Recent papers are only focusing on external mechanism (Brammer \& Pavelin, 2006; Branco \& Rodrigues, 2008; Yao, Wang, \& Song, 2011)or internal mechanism (Eng \& Mak, 2003; Handajani et al., 2014; Rao \& Tilt, 2016b)only. This study fills the gap by using both the effect of internal mechanism (board diversity) measured by board size, board tenure, and women on board, and the effect of external mechanism (public visibility) measured by profitability, company size, and listing age to corporate social responsibility disclosure.

This research contributes on corporate governance and corporate social responsibility research by analyzing the relationship between internal and external mechanisms in increasing corporate social responsibility disclosure. This research also contributes to regulator in making corporate governance regulation by considering company's public visibility to increase corporate social responsibility disclosure more efficiently.

\section{LITERATURE STUDY/HYPOTHESES DEVELOPMENT}

According to legitimacy theory, companies have social contract with the society around them to be legitimate to ascertain companies' survival (Deegan \& Unerman, 2011; Tilling, 2004). The contract enforce companies to fulfil or exceed society's needs to survive in market competition (Zheng, Luo, \& Maksimov, 2015). The society, which is directly or indirectly related to companies, whose needs should be fulfilled is called stakeholder. Stakeholder is a group or individual that influences companies' achievement(Velasquez, 2012). Stakeholder theory states that the companies' purpose is not only shareholders' wealth but also stakeholders' wealth. Stakeholders' wealth can be achieved by fulfilling stakeholders' needs, balancing conflict among them, and building good relationship with them with the help of corporate social responsibility. Corporate social responsibility is organization's responsibility to environment and society for its decision and activities through ethical and transparent action which contributes to sustainable development, including society's health and well-being, considers stakeholder expectation, are in accordance with applicable laws and norms of conduct, and is integrated within the organization thoroughly (ISO, 2010). Companies should disclose their corporate social responsibility as a form of accountability to stakeholders and thus show stakeholders that they are able to achieve stakeholders' wealth(Zheng et al., 2015). Although listed companies in Indonesia are required to disclose their social responsibility, there is no standard for social responsibility disclosure. Therefore, corporate social responsibility disclosure depends on the makers, which are companies' managers, and owners, which are shareholders. However, depending on the companies' managers and owners only can not guarantee the disclosure quantity because they may have different moral values and different interests (according to agency theory)(Rao \& Tilt, 2016b). This is where supervisory role is needed.

Indonesia use two-tier system, system that separates board of director as executor and board of commissioner as supervisor(OECD, 2015). Internal mechanism of supervisor (board of commissioner) is proven to associate with corporate social responsibility disclosure (Eng \& Mak, 2003; Handajani et al., 2014; Rao \& Tilt, 2016b). According to resource dependence theory, companies select their resources carefully to minimize external factors, which may influence them (different stakeholders' interests, uncertainty in moral values and different interests between owner and manager) (Pfeffer \& Salancik, 1978). Companies have to select their board of commissioners carefully to control all the uncertainties from external factors as 
board of commissioners are internal mechanism used to build relationships between companies and stakeholders. Variety of board of commissioner members increases value in discussion(Carter, Simkins, \& Simpson, 2003) and increases the quality of decision and analysis (Fairfax, 2005). Board of commissioner has crucial role in decreasing agency conflict between manager and stakeholder by monitoring corporate social responsibility activities and disclosing these activities to gain legitimacy. Hafsi dan Turgut (2013)say that the diversity of the board of commissioners can be divided into two groups, structural diversity and demographic diversity. Structural diversity is the size, independence, share ownership, and duality of the board. Demographic diversity in the form of gender, ethnicity, age, board experience. This study uses a structural diversity component (board size) as well as demographic diversity (women on board and board tenure).

Board size is the number of board of commissioner in a particular time(Handajani et al., 2014). Board size association on corporate social responsibility disclosure are inconclusive. There is evidence in support of a positive impact of frequency, but there is also evidence to the contrary. Argument from agency theory said that larger boards tend to have larger agency problem due to conflict of interest and coordination issues. Larger boards also could result in flawed incentives in terms of free rider behavior(McConnell \& Servaes, 1990) and reduces flexibility and dynamism in decision making process such as in making corporate social responsibility activities and disclosing it(Dienes \& Velte, 2016). On the other hand, resource based theory suggests that more board members will generate more exchange of ideas and experiences and the larger the number board of commissioners the stronger influence they have to pressure management to reveal more corporate social responsibility information (Handajani et al., 2014; Said, Hj Zainuddin, \& Haron, 2009). More boards also results in more time and more specialist resources to supervise corporate social responsibility disclosure process(Dienes \& Velte, 2016). Although debatable, most researches in Indonesia find positive association of board size and corporate social responsibility disclosure(Handajani et al., 2014; Putra, 2009; Sembiring, 2005; Siregar $\&$ Bachtiar, 2010). In addition, Majeed et al(2015) conclude that board size informs the level of disclosure and transparency of a company. Larger board equals to larger transparency and disclosure.

Ha1: board size is positively associated with corporate social responsibility disclosure

Women on board is the number of women in board of commissioners chair (Handajani et al., 2014). The existence of women on board adds unique and different perspective, experiences and work style in relation to male commissioners(Giannarakis, 2014). Researches indicate that women are more concerned with altruism which leads to more pro-social behavior(Kruger, 2010). Women are more charitable(Williams, 2003) and corporate social performance oriented which leads to increase in company's reputation(Bear et al., 2010). Company with the ratio of the number of female boards has a strong and positive relationship to social responsibility with respect to employee welfare(Handajani et al., 2014).The existence of women boards can make companies more aware of social responsibility and provide a better perspective when formulating social responsibility programs and disclosures (Williams, 2003).The existence of the number of female directors in the board structure also increases the commitment to carry out social activities in order to improve the welfare of the community around the company. This is because of the awareness that the implementation of corporate social responsibility has a good impact 
for the company in the future (Bear et al., 2010). Even some countries have initiated to increase the role of women in boards, such as Norway, Sweden, Spain, France and Italy (Rao \& Tilt, 2016b).

However, psychology researcbes also prove that women are more risk averse and tend to prevent risky projects(Byrnes, J.P., Miller, D.C., Schafer, 1999; Rutterford \& Maltby, 2007). Corporate social responsibility activities are risky projects because its effects are invisible and need long term commitment(Perez-Batres, Doh, Miller, \& Pisani, 2012; Simsek, Veiga, \& Lubatkin, 2007). Therefore the existence of women on board can also negatively associated with corporate social responsibility disclosure.

Despite the conflicted results, researches find more positive association than negative association of women on board and corporate social responsibility disclosure.

Ha2: women on board is positively associated with corporate social responsibility disclosure

Board tenure is the length of a member of board of commissioner within a company. Board tenure has a two-sided impact on corporate social responsibility disclosure. On the one hand, board tenure supporters say longer board tenure increases the board's knowledge of the company (Kruger, 2010). Longer board tenure also allows the board of commissioners to oversee senior managers, reduce vulnerability to pressure, and reduce managers' control (Livnat, Smith, Suslava, \& Tarlie, 2015). Longer board tenure is better at monitoring corporate activities as the boards can gather valuable information and can disclose it to independent board members, which in turn can improve the company's performance, including in disclosing its social responsibility(Livnat et al., 2015). On the other hand, board tenure could reduce the independence of the board of commissioners as it becomes more familiar with companies managers (management friendliness hypothesis) (Vafeas, 2003). Berberich and $\mathrm{Niu}$ (2011)found a positive influence between longer board tenure with governance issues, such as bankruptcies, corporate scandals, litigation, and so on. It also affected corporate social responsibility implementation and reporting.

The negative association of board tenure on corporate social responsibility is an indirect impact. Kruger(2010) discloses the direct positive impact of board tenure on corporate social responsibility whereby longer board tenure is more long-term oriented which is more concerned about corporate social responsibility. disclosure

Ha3: board tenure is positively associated with corporate social responsibility

Internal supervisory mechanism is not enough to make sure that companies will pursue stakeholders' wealth. Stakeholders have to supervise the companies as the external supervisory mechanism. Legitimacy theory indicates that corporate social responsibility is a response of public pressure and public visibility on social incident(Patten, 1992). High public visibility level companies will get more supervision from stakeholders and thus have more pressure to disclose more corporate social responsibility activities. Previous researchers used many measurements to measure the level of public visibility. Yao et al (2011) use customer proximity industry, media exposure, and company age to measure the level of public visibility while Branco and Rodriguez(2008) use company size, employee size, and profitability. This study uses firm size, company age (listing age) and profitability. Listing age is used because when the company is listed on the stock exchange, the level of its public visibility is higher so that listing age is more suitable to measure the level of public visibility. 
Company size is the most common measurement used to measure the level of public visibility. Companies that have large scales usually do more disclosure of social responsibility when compared with small-scale companies. Large companies usually have more activities, complex, and have greater impact on society, have more shareholders and get public attention (public visibility) and therefore large-scale companies are under pressure to disclose their social responsibility(Brammer \& Pavelin, 2006; Schreck \& Raithel, 2018). disclosure

Ha4: company size is positively associated with corporate social responsibility

Profitability is a relationship between income and expense caused by the use of a company's assets either current assets or fixed assets in the company's production activities. The level of company profitability can attract the attention of stakeholders. Profitability of a company affects level of public visibility of the company and thus impacting the disclosure of its social responsibility(Gamerschlag et al., 2011). This is because the higher the level of profitability, the higher the level of public visibility and the greater the funds that can and should be allocated for social responsibility activities. Hibbit (2003)argues that companies that present abnormally high levels of profits are exposed to public pressures from relevant publics as if the companies operate in socially sensitive industries. disclosure

Ha5: profitability is positively associated with corporate social responsibility

Listing age is a length of time a company listed on the capital market as a public company. Listing age is a critical factor to determine the extension of corporate social responsibility disclosure and greatly affects the level of social responsibility disclosure in company's financial statements (Bayoud, Kavanagh, \& Slaughter, 2012). The longer a company is listed on the capital market, the greater its level of public visibility and thus affecting the level of its social responsibility disclosure (Khan, Muttakin, \& Siddiqui, 2013). The long-listed companies show their existence through activities related to the community such as social activities. These activities are expected to increase investor confidence(Bayoud et al., 2012).

On the other hand, newly listed in capital market shows that the company needs more financing. To get more financing from shareholder, these companies disclose more corporate social responsibility to gain legitimacy(Yao et al., 2011). Companies that are long listed on capital market have less incentive to disclose corporate social responsibility due to less financial problem.

Researchers find more results in positive association than negative association between listing age and corporate social responsibility disclosure. Therefore, it is hypothesized that listing age is positively associated with corporate social responsibility disclosure.

Ha6: listing age is positively associated with corporate social responsibility disclosure

Corporate social responsibility disclosure depends on the efficiency of a bundle of mechanisms to mitigate agency problem. Internal and external mechanisms are both mitigating agency problem(Rediker \& Seth, 1995). The impact of any one mechanism might be insufficient to achieve the alignment of manager-stakeholder interest but the 
overall effect of the bundle of mechanisms might be sufficient. On contrary, the impact of any one mechanism might be sufficient to mitigate agency problem and do not need all mechanisms. Rediker and Seth(1995) define in the context of regression methodology. In this context, there might be an important consequences of omitting relevant independent variables. If an omitted explanatory variable is not related to independent variables, its omission may not have serious consequences for least square estimation. However if it is related to independent variables, the estimated coefficient of the included variable will be both biased and inconsistent. In terms of this research, it might be that highly visible companies do not need strict or best supervisory to make companies disclose their social responsibility better. The strict supervisory may have reverse impact on corporate social responsibility disclosure, for example strict supervision of shareholder oriented board of commissioners will restrain the company to do and disclose social responsibility activities. This results in substitution effect of internal mechanism and external mechanism on corporate social responsibility disclosure. On the other hand, high visibility may not sufficient to push directors on disclosing corporate social responsibility. Strict supervision from stakeholder oriented board of commissioner encourage the company to disclose social responsibility activities. These contradicting relationship has not been proven by previous researches. Therefore:

Ha7a: internal mechanism and external mechanism in increasing corporate social responsibility disclosure are substitutes

Ha7b: internal mechanism and external mechanism in increasing corporate social responsibility disclosure are complementary

\section{RESEARCH METHODOLOGY}

Data are manually obtained from companies' annual reports. This research uses SPSS Statistics 19 with pooled data analysis. Multiple regression is used to see the value of dependent variable based on multiple independent variables values. The equation is as follow:

$$
\begin{aligned}
C S R D_{i t}= & \beta_{0}+\beta_{1} B S I Z E_{i t}+\beta_{2} W O B_{i t}+\beta_{3} T E N_{i t}+\beta_{4} F S I Z E_{i t}+\beta_{5} P R O F_{i t}+ \\
& \beta_{6} A G E_{i t}+\varepsilon_{i t}
\end{aligned}
$$

CSRD $=$ Corporate Social Responsibility Disclosure

BSIZE $=$ Board Size

WOB $=$ Women on Board

TEN $=$ Board Tenure

FSIZE $=$ Firm Size

PROF = Profitability

AGE $=$ Listing Age

Corporate social responsibility disclosure is measured according to Sembiring(2005).This measurement is used because Sembiring tailored corporate social responsibility disclosure measurement especially for Indonesian companies, considering Indonesian circumstances and policies and there is no additional policy regarding corporate social responsibility disclosure ever since. If the disclosure item is exist in the company's annual report, it is assigned a value of 1 and if the item is not exist it will be given a value of 0 . The number of disclosure is summed and divided by 78 , the maximum value.

Board diversity is measured by board size, women on board, and board tenure. Board size is measured by the number of board of commissioner on board (Das, Dixon, $\&$ Michael, 2015). Women on board is measured by the number of women in the board of commissioner(Handajani et al., 2014). Board tenure is measured by the average terms (years) board of commissioner working in the company(Kruger, 2010; Yao et al., 2011) 
Public visibility is measured by firm size, profitability, and listing age. Company size is measured using natural logarithm of total assets owned by the company (Hafsi \& Turgut, 2013; Wang et al., 2011). Profitability is measured by net profit margin(Gamerschlag et al., 2011). Listing age is measured from the length of the company listed on the Indonesia Stock Exchange(Das et al., 2015).

This research focuses on corporate social responsibility disclosure in companies' annual report for manufacturing companies listed in Indonesian Stock Exchange from 2013 to 2015. Annual report is used because social responsibility report contained in the annual report is the type of report that was first produced and is the most common report(Hackston \& Milne, 1996). Manufacturing companies are used because manufacturing companies are companies that have complex activities that enable companies to engage in social activities and disclosures more transparently. In addition, the manufacturing industry also has a higher risk of pollution, since waste generated from the production process will be very dangerous if not treated properly so it is suitable to be used in social responsibility research.

To prove substitution or complementary relationship between internal and external mechanism, this research runs three separate multiple regressions on internal and external mechanisms; ie. Multiple regression of internal mechanism and corporate social responsibility disclosure, multiple regression of external mechanism and corporate social responsibility disclosure, multiple regression of both internal and external mechanism and corporate social responsibility disclosure.

This paper constructs the sample starting with all manufacturing companies listed on fact book 2014-2016. Companies in the final sample meet the following criteria:

1. The company is consistently listed in Indonesia Stock Exchange from 2013-2015

2. The company submits complete annual report and financial statement during 20132015

3. The company has separate corporate social responsibility section in annual report

4. The company uses local currency (Rupiah) in financial statement and annual report

5. The company earns profit during 2013-2015

6. The company discloses board of commissioners' tenure in annual report

From the criteria above, the number of samples is 59 companies or 177 observations.

\section{RESULTS}

Table 1 Descriptive Statistics

Std.

Std.

Variables N Minimum Maximum Mean Deviation Variables N Minimum Maximum Mean Deviation

\begin{tabular}{llllllllllll}
\hline CSRD & 177 & 0,0897 & 0,6026 & 0,2513 & 0,1243 & FSIZE & 177 & 25,6195 & 33,1341 & 28,3584 & 1,6932 \\
BSIZE & 177 & 2 & 11 & 4,29 & 1,926 & PROF & 177 & 0,0011 & 0,5087 & 0,0856 & 0,0765 \\
WOB & 177 & 0 & 3 & 0,33 & 0,60927 & AGE & 177 & 1 & 35 & 19,68 & 8,338 \\
TEN & 177 & 1,33 & 25.33 & 8,7865 & 5,65223 & & & & & &
\end{tabular}

From Table 1, it can be seen that the board of commissioners in manufacturing companies in Indonesia has an average of 4-5 people but only about 0-1 woman in the board of commissioners. This shows how minimum the number of women in the board of commissioners in Indonesia. Boards tenure in manufacturing companies in Indonesia vary widely, ranging from 1 to 25 years, so do profitability $(0-50 \%)$ and listing age (1-35 years). 
AFEBI Accounting Review (AAR)

Vol.03 No.02, December 2018

Table 2 Pearson Correlation Test

\begin{tabular}{|c|c|c|c|c|c|c|c|}
\hline & CSRD & BSIZE & TEN & PROF & AGE & FSIZE & WOB \\
\hline CSRD & 1 & $.657 * *$ & -.096 & $.453^{* *}$ & .069 & $.644 * *$ & -.153 \\
\hline BSIZE & $.657 * *$ & 1 & $-.214 *$ & .154 & $.183^{*}$ & $.726^{* *}$ & -.176 \\
\hline TEN & -.096 & $-.214^{*}$ & 1 & -.005 & .125 & $-.239 * *$ & $-.404 * *$ \\
\hline PROF & $.453 * *$ & .154 & -.005 & 1 & .016 & .160 & -.130 \\
\hline AGE & .069 & $.183^{*}$ & .125 & .016 & 1 & .165 & -.173 \\
\hline FSIZE & $.644 * *$ & $.726^{* *}$ & $-.239 * *$ & .160 & .165 & & -.016 \\
\hline WOB & -.153 & -.176 & $-.404 * *$ & -.130 & -.173 & -.016 & 1 \\
\hline
\end{tabular}

Pearson correlation test show that board size, profitability, and firm size are correlated with corporate social responsibility disclosure. However, these correlations do not consider other variables associating with corporate social responsibility disclosure. Therefore, $\mathrm{t}$ test is done.

Table 3 Hypothesis Test Results

\begin{tabular}{|c|c|c|c|c|c|c|}
\hline & coefficients & sig & coefficients & sig & coefficients & sig \\
\hline constant & 0,085 & 0,015 & & & $-0,695$ & 0,000 \\
\hline BSIZE & 0,039 & $0,000 * * *$ & & & 0,015 & $0,002 * * *$ \\
\hline TEN & 0,001 & 0,652 & & & 0,001 & 0,506 \\
\hline$W O B$ & $-0,006$ & 0,79 & & & $-0,029$ & $0,012 * *$ \\
\hline$P R O F$ & & & 0,585 & $0,000 * * *$ & 0,479 & $0,000 * * *$ \\
\hline$A G E$ & & & $-0,001$ & 0,595 & $-0,001$ & $0,075^{*}$ \\
\hline FSIZE & & & 0,041 & $0,000 * * *$ & 0,031 & $0,000 * * *$ \\
\hline $\mathrm{R}$ & & 0,659 & & 0,736 & & 0,725 \\
\hline Adjusted & & 0,419 & & 0,529 & & 0,509 \\
\hline $\mathrm{R}$ & & & & & & \\
\hline Square & & & & & & \\
\hline
\end{tabular}

Before performing multiple regression analysis, the model test is performed to see whether the data are fit, normal, no multicollinearity, no heteroscedasticity, and no autocorrelation. The data used in this research are fit (significant level of F statistics are 0,000$)$, normal $(0,761)$, no multicollinearity (VIF are less than 10 and tolerance are more than 0,1 ), no heteroscedasticity (significant levels are not less than 0,05), and no autocorrelation (significant level of residual $=0,462$ ).

The hypothesis test is divided into 3 sections, i.e. internal mechanism, external mechanism, and both. It is clear that external mechanism is more strongly associated with corporate social responsibility disclosure than internal mechanism or both mechanism. Considering internal mechanism only, board size is positively associated with corporate social responsibility disclosure. This association remains stable when external mechanism is considered, meaning Ha1 is accepted. Women on board is negatively associated with the disclosure of social responsibility when external mechanism are considered. Therefore, $\mathrm{Ha} 2$ is not accepted. Board tenure does not associate with corporate social responsibility disclosure in both models. Thus, Ha3 is not accepted Considering external mechanism only, profitability and firm size are positively associated with corporate social disclosure, meaning $\mathrm{Ha} 4$ and $\mathrm{Ha} 5$ are accepted. The associations remain even after considering internal mechanism. Company listing age is not associated with corporate social disclosure when only external mechanism is exists. However, when considering both mechanism, listing age is negatively associated with corporate social disclosure. Ha7 is not accepted. 
Intrigued by debates over board tenure effect on corporate social responsibility, this paper makes an additional research on how many years do board tenure associates with corporate social responsibility disclosure. Byrd et al(2010) finds that board tenure should be less than 6 years or it will harm board's independence. Livnat et al(2015) finds that board tenure should be less than 9 years on average. Vafeas(2003) uses longer tenure, which is 20 years. Analysing these three criteria, surprising results are shown on Table 4.

Table 4 Additional Test Results

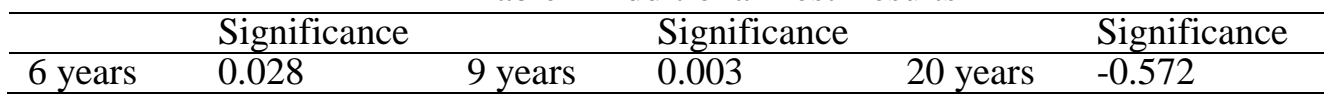

Different from other researches, companies which have board tenure more than 6 years and 9 years have more corporate social responsibility disclosure while companies which have more than 20 years of board tenure do not differ with companies which have less than 20 years of board tenure. These results are surprising because these show that Indonesian companies depend on their long lasting board of commissioner. Even with twenty years length of time, short board tenure companies' corporate social responsibility disclosure still cannot defeat long board tenure companies' corporate social responsibility disclosure, although there is a tendency. These results also support the findings of listing age. The younger the companies are listed in stock exchange, the less the corporate social responsibility disclosures are. This may be due to short tenure board of commissioner they have to push the younger companies to disclose their corporate social responsibility.

Companies which have higher profitability will give motivation to the manager to provide more detailed information to show and account for the social program that has been made by the manager(Hermawan \& Mulyawan, 2014). Due to the high level of public visibility, the companies must use their excess profits to gain legitimacy from their stakeholders.

\section{DISCUSSION}

This study shows how internal mechanism and external mechanism' role in corporate social responsibility disclosure. Multiple regression test for both internal mechanism and external mechanism shows that board size is positively associated with corporate social responsibility disclosure. This is in line with resource dependence theory that more boards results in more time and more specialist resources to supervise corporate social responsibility disclosure process(Dienes \& Velte, 2016). However, board tenure does not have association with corporate social responsibility disclosure. The conflicted association between board tenure and corporate social responsibility disclosure which come from lack of independence and increased knowledge results in no effect of board tenure on corporate social responsibility disclosure. This could be indication of nonlinear relationship. Additional test shows that 6 years and 9 years tenure are positively associated with corporate social responsibility disclosure but 20 years tenure has no association with corporate social responsibility disclosure. Women on board are negatively associated with corporate social responsibility disclosure. This shows that women on board in Indonesia manufacturing companies regards corporate social responsibility as risky project. Therefore they do not support social responsibility activities which equals to less disclosure on social responsibility activities.

Profitability and firm size are also positively associated with corporate social responsibility disclosure. In accordance with legitimacy theory, companies that are more visible need more legitimacy to survive. However, listing age is negatively associated with corporate social responsibility disclosure. This shows that newly listed companies need more financing and need more legitimacy which results in more corporate social responsibility disclosure(Yao et al., 2011). 
To see the relationship between external mechanism and internal mechanism, this study runs separate multiple regression on the association of each mechanism on corporate social responsibility disclosure. Data shows interesting result. The association of external mechanism and internal mechanism to corporate social responsibility disclosure are substitution. The coefficient amount of internal mechanism and external mechanism relation to corporate social responsibility disclosure are bigger than they exist in the same time. The negative associations to corporate social responsibility disclosure are also bigger when both mechanisms exist. Without other types of mechanism, women on board and firm age does not associate with corporate social responsibility disclosure. But when other types of mechanism exist, they are negatively associated with corporate social responsibility disclosure. Families own the majority of companies in Indonesia and women within the board are from families who own the companies, not because of their competence(Yao et al., 2011). In addition, because women on board represent the families, companies do not need to disclose its social responsibility to the minority shareholders, the public, because their majority shareholder (family) know how the companies are operated(Rudyanto \& Siregar, 2018). Agency theory states that information asymmetry between majority shareholder and other stakeholders should be reduced by agency cost This is severely triggered by company listing age. Young companies require greater disclosure of corporate social responsibility because they require visibility from investors and banks to get funding from them(Yao et al., 2011). Women on board in old companies are usually coming from family. As the owner of the company, women are more risk averse than men or than women in general(Rutterford \& Maltby, 2007). Family has agency problem with stakeholders and tend to maximize their own wealth by not taking risky investment(Nekhili, Nagati, Chtioui, \& Rebolledo, 2017) Making corporate social responsibility activities and disclosing them are long term investment which is very risky. Therefore, women on board in old firms are negatively associated with corporate social responsibility disclosure.

The association of board size, board tenure, company size with corporate social responsibility disclosure are stable, although the coefficients are decreasing. The larger the board of commissioners size, the most likely the company is to disclose the social responsibility. Board size increases the power to put pressure on management in disclosing social responsibility, so the company which has larger number of board of commissioner, is likely to disclose more social responsibility(Carter et al., 2003; Said et al., 2009). The duration of board tenure does not associate with the disclosure of social responsibility in Indonesia because the newly appointed board of commissioners are largely the ex-board of directors. Long board tenure also can impair board of commissioners' independence(Vafeas, 2003), increase governance problem (Berberich \& Niu, 2011) and lack of critical thinking by board members(Rao \& Tilt, 2016b).Therefore, the positive and negative association of board tenure and corporate social responsibility disclosure collide, giving no association with corporate social responsibility disclosure.

Large companies usually get attention from the public (public visibility). Therefore, large-scale companies tend to do and disclose corporate social responsibility activities more so that companies get legitimacy from stakeholders(Schreck \& Raithel, 2018). This indicates that companies just have to choose one of the mechanism to increase corporate social responsibility disclosure.

\section{CONCLUSION}

Internal and external supervisory mechanism are expected to positively associated with corporate social responsibility disclosure. However, not all of the mechanism are effective in increasing corporate social responsibility (women on board, board tenure, and listing age). Women on board, board tenure, and listing age do not increase corporate social responsibility maybe because there are other factors affecting them. Women on board maybe affected by their roles as family in family firms. Board 
tenure maybe because of reversing effect on longer tenure. Listing age maybe because of board tenure. Further research is needed to find other factors associating with these variables, with regard of their effect on corporate social responsibility to produce valuable findings. Further research can also use other measurements for dependent and independent variables to test whether these independent variables are truly associated with corporate social responsibility disclosure. Board diversity can also be measured by Blau Index or other structural and demographic diversity(Hafsi \& Turgut, 2013). Public visibility can also be measured by customer proximity industry(Rudyanto \& Siregar, 2018), media exposure(Yao et al., 2011), and employee size(Branco \& Rodrigues, 2008). Next researcher also can analyse how long the board tenure impact is on corporate social responsibility disclosure and why the characteristic of Indonesian companies are different with other countries.

This paper shows that internal and external mechanisms are substitutes. A highly visible company does not need strict supervisory to increase corporate social responsibility disclosure. Market pressure is effective enough to push companies to disclose corporate social responsibility. This also proves that board of commissioners in Indonesian companies are shareholder oriented.This paper is not without caveat. Corporate governance variables are companies' choice, thus those are endogenous variables. However, this paper does not control this problem. This paper also only uses manufacturing companies and do not consider other industries that maybe as close as or maybe closer to social responsibility, such as environmentally sensitive industries. This paper is also limited in data. Data limitation affects the association of independent and dependent variables. Future researches should consider these limitations.

Regardless the limitations, this paper highlights how internal mechanism and external mechanism role in corporate social responsibility disclosure. The results contribute to policy making. Corporate governance is not 'one size fits all'. Seeing how internal mechanism and external mechanism are substituted, government shall not force strong corporate governance mechanism when the company visibility is already strong. This paper also contributes to corporate social responsibility paper by adding knowledge of substitution effect of internal and external mechanism on corporate social responsibility disclosure.

\section{References}

Bayoud, N. S., Kavanagh, M., \& Slaughter, G. (2012). Factors Influencing Levels of Corporate Social Responsibility Disclosure by Libyan Firms: A Mixed Study. International Journal of Economics and Finance, 4(4), 13-30. https://doi.org/10.5539/ijef.v4n4p13

Bear, S., Rahman, N., \& Post, C. (2010). The Impact of Board Diversity and Gender Composition on Corporate Social Responsibility and Firm Reputation. Journal of Business Ethics, 97(2), 207-221. https://doi.org/10.1007/s10551-010-0505-2

Berberich, G., \& Niu, F. (2011). Director Busyness , Director Tenure and the Likelihood of Encountering Corporate Governance Problems. Journal of Corporate Governance, (January), 1-23.

Brammer, S., \& Pavelin, S. (2006). Voluntary Environmental Disclosures by Large UK Companies. Journal of Business Finance \& Accounting, 33(7-8), 1168-1188. https://doi.org/10.1111/j.1468-5957.2006.00598.x

Branco, M. C., \& Rodrigues, L. L. (2008). Factors influencing social responsibility disclosure by Portuguese companies. Journal of Business Ethics, 83(4), 685-701. https://doi.org/10.1007/s10551-007-9658-z

Byrd, J., Cooperman, E. S., \& Wolfe, G. A. (2010). Director tenure and the compensation of bank CEOs. Managerial Finance, 36(2), 86-102. 
https://doi.org/10.1108/03074351011014523

Byrnes, J.P., Miller, D.C., Schafer, W. D. (1999). Gender differences in risk taking. Psychological Bulletin, 125(3), 367-383. https://doi.org/10.1037/00332909.125.3.367

Carter, D. A., Simkins, B. J., \& Simpson, W. G. (2003). Corporate Governance, Board Diversity, and Firm Value. The Financial Review, 38(1), 33-53. https://doi.org/10.1111/1540-6288.00034

Corbetta, G., \& Salvato, C. (2004). The Board of Directors in Family Firms: One Size Fits All? Family Business Review, 17(2), 119-134. https://doi.org/10.1111/j.1741-6248.2004.00008.x

Das, S., Dixon, R., \& Michael, A. (2015). Corporate Social Responsibility Reporting: A Longitudinal Study of Listed Banking Companies in Bangladesh. World Review of Business Research, 5(1), 130-154. https://doi.org/10.1108/17471110910977276

Deegan, C., \& Unerman, J. (2011). Unregulated corporate reporting decisions: considerations of systems-oriented theories. In Financial accounting theory. London: McGraw-Hill.

Detik. (2016). Jejak Kasus: Mengungkap Berita Berdasarkan Fakta. Retrieved July 4, 2017, from http://jejakkasus.info/2016/08/pembuangan-limbah-pt-jayamestika.html

Dienes, D., \& Velte, P. (2016). The Impact of Supervisory Board Composition on CSR Reporting . Evidence from the German Two-Tier System. Sustainability (Switzerland), 8(63), 1-20. https://doi.org/10.3390/su8010063

Eng, L. L., \& Mak, Y. T. (2003). Corporate governance and voluntary disclosure. Journal of Accounting and Public Policy, 22(4), 325-345. https://doi.org/10.1016/S0278-4254(03)00037-1

Fairfax, L. M. (2005). THE BOTTOM LINE ON BOARD DIVERSITY : A COSTBENEFIT ANALYSIS OF THE BUSINESS RATIONALES FOR DIVERSITY ON CORPORATE BOARDS Lisa M . Fairfax University of Maryland School of Law THE BOTTOM LI. Wisconsin Law Review, 795-853.

Frias-Aceituno, J. V., Rodriguez-Ariza, L., \& Garcia-Sanchez, I. . (2013). The Role of the Board in the Dissemination of Integrated Corporate Social Reporting. Corporate Social Responsibility and Environmental Management, 20(4), 219233. https://doi.org/10.1002/csr.1294

Gamerschlag, R., Möller, K., Verbeeten, F., Gamerschlag, R., Möller, Á. K., \& Verbeeten, F. (2011). Determinants of voluntary CSR disclosure: empirical evidence from Germany. Rev Manag Sci, 5(1), 233-262. https://doi.org/10.1007/s11846-010-0052-3

Giannarakis, G. (2014). Corporate governance and financial characteristic effects on the extent of corporate social responsibility disclosure. Social Responsibility Journal, 10(4), 569-590. https://doi.org/10.1108/SRJ-02-2013-0008

Hackston, D., \& Milne, M. J. (1996). Some determinants of social and environmental disclosures in New Zealand companies. Accounting, Auditing \& Accountability Journal, 9(1), 77-108. https://doi.org/10.1108/09513579610109987

Hafsi, T., \& Turgut, G. (2013). Boardroom Diversity and its Effect on Social Performance: Conceptualization and Empirical Evidence. Journal of Business 
Ethics, 112(3), 463-479. https://doi.org/10.1007/s10551-012-1272-z

Handajani, L., Subroto, B., \& Erwin, S. T. (2014). Does Board Diversity Matter on Corporate Social Disclosure? An Indonesian Evidence. Journal of Economics and Sustainable Development, 5(9), 8-17.

Hermawan, M. S., \& Mulyawan, S. G. (2014). Profitability and Corporate Social Responsibility: an Analysis of Indonesia' S Listed Company. Asia Pacific Journal of Accounting and Finance, 3(1), 15-31.

Hibbit, C. (2003). External Environmental Disclosure and Reporting by Large European Companies: An Economic, Social and Political Analysis of Managerial Behaviour. Limperg Instituut.

ISO. (2010). ISO 26000 : Guidance on Social Responsibility.

Kathy Rao, K., Tilt, C. A., \& Lester, L. H. (2012). Corporate governance and environmental reporting: an Australian study. Corporate Governance: The International Journal of Business in Society, 12(2), 143-163. https://doi.org/10.1108/14720701211214052

Khan, A., Muttakin, M. B., \& Siddiqui, J. (2013). Corporate Governance and Corporate Social Responsibility Disclosures: Evidence from an Emerging Economy. Journal of Business Ethics, 114(2), 207-223. https://doi.org/10.1007/s10551012-1336-0

Kruger, P. (2010). Corporate Social Responsibility and the Board of Directors. Geneva Finance Institute, (Working paper).

Livnat, J., Smith, G., Suslava, K., \& Tarlie, M. (2015). Do Directors Have a Use-By Date? Examining the Impact of Board Tenure on Firm Performance, 6(4), 408418.

Majeed, S., Aziz, T., \& Saleem, S. (2015). The Effect of Corporate Governance Elements on Corporate Social Responsibility (CSR) Disclosure: An Empirical Evidence from Listed Companies at KSE Pakistan. International Journal of Financial Studies, 3(4), 530-556. https://doi.org/10.3390/ijfs3040530

McConnell, J., \& Servaes, H. (1990). Additional evidence on equity ownership and corporate value. Journal of Financial Economics, 27(2), 595-612.

Nekhili, M., Nagati, H., Chtioui, T., \& Rebolledo, C. (2017). Corporate social responsibility disclosure and market value: Family versus nonfamily firms. Journal of Business Research, 77(July 2016), 41-52. https://doi.org/10.1016/j.jbusres.2017.04.001

OECD. (2015). G20/OECD Principles of Corporate Governance. Turkey. https://doi.org/10.1787/9789264015999-en

Patten, D. M. (1992). Intra-industry environmental disclosures in response to the Alaskan oil spill: A note on legitimacy theory. Accounting, Organizations and Society, 17(5), 471-475. https://doi.org/10.1016/0361-3682(92)90042-Q

Pemerintah Republik Indonesia. (2007). Undang-Undang Republik Indonesia Nomor 40 Tahun 2007 tentang Perseroan Terbatas.

Perez-Batres, L. A., Doh, J. P., Miller, V. V., \& Pisani, M. J. (2012). Stakeholder Pressures as Determinants of CSR Strategic Choice: Why do Firms Choose Symbolic Versus Substantive Self-Regulatory Codes of Conduct? Journal of Business Ethics, 110(2), 157-172. https://doi.org/10.1007/s10551-012-1419-y 
Pfeffer, J., \& Salancik, G. (1978). The External Control of Organizations: A Resource Dependence Perspective | Stanford Graduate School of Business. Harper\&Row. Retrieved from https://www.gsb.stanford.edu/faculty-research/books/externalcontrol-organizations-resource-dependence-perspective

Purwanto, A. (2011). Pengaruh Tipe Industri, Ukuran Perusahaan, Profitabilitas terhadap Corporate Social Responsibility. Jurnal Akuntansi \& Auditing, 8(1), 194. Retrieved

from http://ejournal.undip.ac.id/index.php/akuditi/article/view/4344

Putra, R. A. (2009). Analisis Faktor-Faktor yang Mempengaruhi Pengungkapan Tanggung Jawab Sosial serta Hubungan Pengungkapan Tanggung Jawab Sosial dengan Reaksi Investor. Universitas Indonesia.

Rao, K., \& Tilt, C. (2016a). Board Composition and Corporate Social Responsibility : The Role of Diversity, Gender, Strategy and Decision Making. Journal of Business Ethics, 327-347. https://doi.org/10.1007/s10551-015-2613-5

Rao, K., \& Tilt, C. (2016b). Board diversity and CSR reporting: an Australian study. Meditari Accountancy Research, 24(2). https://doi.org/10.1108/09574090910954864

Rediker, K. J., \& Seth, A. (1995). Boards of Directors and Substitution Effects of Alternative Governance Mechanisms. Strategic Management Journal, 16(2), 85100. https://doi.org/10.1007/s10295-007-0219-3

Rudyanto, A., \& Siregar, S. V. N. P. (2018). The effect of stakeholder pressure and cg on the quality of sustainability report. The International Journal of Ethics and Systems, 34(2), 233-249.

Rutterford, J., \& Maltby, J. (2007). "The nesting instinct": women and investment risk in a historical context. Accounting History, 12(3), 305-327. https://doi.org/10.1177/1032373207079035

Said, R., Hj Zainuddin, Y., \& Haron, H. (2009). The relationship between corporate social responsibility disclosure and corporate governance characteristics in Malaysian public listed companies. Social Responsibility Journal, 5(2), 212-226. https://doi.org/10.1108/17471110910964496

Schreck, P., \& Raithel, S. (2018). Corporate Social Performance, Firm Size, and Organizational Visibility: Distinct and Joint Effects on Voluntary Sustainability Reporting. Business and Society, 57(4), 742-778. https://doi.org/10.1177/0007650315613120

Sembiring, E. R. (2005). KARAKTERISTIK PERUSAHAAN DAN PENGUNGKAPAN TANGGUNG JAWAB SOSIAL: STUDY EMPIRIS PADA PERUSAHAAN YANG TERCATAT DI BURSA EFEK JAKARTA. MAKSI, 6(1), 69-85. Retrieved from http://mahasiswa.dinus.ac.id/docs/skripsi/jurnal/12943.pdf

Simsek, Z., Veiga, J. F., \& Lubatkin, M. H. (2007). The impact of managerial environmental perceptions on corporate entrepreneurship: Towards understanding discretionary slack's pivotal role. Journal of Management Studies, 44(8), 1398-1424. https://doi.org/10.1111/j.1467-6486.2007.00714.x

Siregar, S. V. N. P., \& Bachtiar, Y. (2010). Corporate social reporting: empirical evidence from Indonesia Stock Exchange. International Journal of Islamic and Middle Eastern Finance and Management, 3(3), 241-252. https://doi.org/10.1108/17538391011072435 
Tilling, M. V. (2004). Communication at the Edge: Voluntary social and environmental reporting in the annual report of a legitimacy threatened corporation, 4-6.

Vafeas, N. (2003). Length of Board Tenure and Outside Director Independence. Journal of Business Finance\&Accounting, 30(7-8), 1043-1064. https://doi.org/10.1111/1468-5957.05525

Velasquez, M. G. (2012). Business ethics : concepts and cases. Pearson Education.

Wang, M., Qiu, C., Kong, D., Journal, S., June, N., \& Wang, M. (2011). Corporate Social Responsibility, Investor Behaviors, and Stock Market Returns : Evidence from a Natural Experiment in China. Journal of Business Ethics, 101(1), 127141. https://doi.org/10.1007/s10551-010-0713-9

Williams, R. J. (2003). Women on corporate boards of directors and their influence on corporate philanthropy. Journal of Business Ethics, 42(1), 1-10. https://doi.org/10.2307/25074940

Williams, R. J. (2003). Women on Corporate Boards of Directors and their Influence on Corporate Philanthropy. Journal of Business Ethics, 42(1), 1-10. https://doi.org/10.1023/A:1021626024014

Yao, S., Wang, J., \& Song, L. (2011). Determinants of Social Responsibility Disclosure By Chinese Firms. The Journal of Applied Business Research, 29(July).

Zheng, Q., Luo, Y., \& Maksimov, V. (2015). Achieving legitimacy through corporate social responsibility: The case of emerging economy firms. Journal of World Business, 50(3), 389-403. https://doi.org/10.1016/j.jwb.2014.05.001 